\title{
UNDERSTANDING THE FORMS OF CARE OF NURSES IN THE OPERATING ROOM - A CONSTRUCTION BASED ON THE GROUNDED THEORY METHOD
}

\author{
Felipe Kaezer dos Santos ${ }^{1}$, Maria Virgínia Godoy da Silva ${ }^{2}$, Antônio Marcos Tosoli Gomes ${ }^{3}$
}

\footnotetext{
${ }^{1}$ Nursing Doctoral Student, Universidade Estadual do Rio de Janeiro (UERJ), School of Nursing. Rio de Janeiro, Rio de Janeiro, Brazil. E-mail: felipe-ks@uol.com.br

${ }^{2}$ Ph.D. in Nursing. Assistant Professor, Department of Medical-Surgical Nursing, UERJ, School of Nursing. Rio de Janeiro, Rio de Janeiro, Brazil. E-mail: godoydasilva@terra.com.br

${ }^{3}$ Ph.D. in Nursing. Assistant Professor, Department of Medical-Surgical Nursing, UERJ, School of Nursing. Rio de Janeiro, Rio de Janeiro, Brazil. E-mail: mtosoli@gmail.com
}

\begin{abstract}
The aim of this study was to identify forms of care of nurses in the operating room, and describe how context influences the implementation of this care. This is qualitative study, for which data were obtained by means of five interviews with nurses working in the operating room of a public hospital in the municipality of Duque de Caxias, in the Brazilian state of Rio de Janeiro, conducted between August and September of 2010, using a semistructured script. The methodology followed the Grounded Theory method. The results show that the nurses perform care motivated by professional commitment and satisfaction, with patient health being their primary focus. Professional context influences ways of working, since the relationship of care exists in the interdependence between the beings involved and working conditions. In conclusion, operating room nurses integrate several factors, acting sometimes as agents of indirect care, despite the difficulties of a complex and specific context.
\end{abstract}

DESCRIPTORS: Hospital surgery department. Operating room nursing. Nursing care.

\section{CONHECENDO AS FORMAS DE CUIDAR DOS ENFERMEIROS DE CENTRO CIRÚRGICO - UMA CONSTRUÇÃO A PARTIR DA TEORIA FUNDAMENTADA NOS DADOS}

RESUMO: Os objetivos deste estudo foram identificar as formas de cuidar do enfermeiro de centro cirúrgico e descrever a influência do contexto para sua realização. Trata-se de pesquisa qualitativa, cujos dados foram obtidos através de cinco entrevistas com enfermeiros de Centro Cirúrgico do município de Duque de Caxias (RJ), realizadas entre agosto e setembro de 2010, através de um roteiro semiestruturado. A metodologia seguiu a Teoria Fundamentada nos Dados. Os resultados mostram que o enfermeiro realiza o cuidado motivado pelo compromisso e satisfação profissional, tendo a preservação do patiente como foco principal. O contexto é apontado como capaz de influenciar as formas de trabalho, já que a relação de cuidado existe na interdependência entre os entes envolvidos e as condições de trabalho. Concluiu-se que os enfermeiros de centro cirúrgico integram diversos fatores, atuando, por vezes, como agentes do cuidado indireto, apesar das dificuldades de um contexto complexo e específico.

DESCRITORES: Centro cirúrgico hospitalar. Enfermagem de centro cirúrgico. Cuidados de enfermagem.

\section{CONOCIENDO LAS FORMAS DE CUIDAR DE ENFERMEROS DEL SERVICIO DE CIRUGÍA - UNA CONSTRUCCIÓN A PARTIR DE LA TEORÍA FUNDAMENTADA EN LOS DATOS}

\begin{abstract}
RESUMEN: Se objetivó identificar las formas de cuidar del enfermero de Servicio de Cirugía y describir la influencia del contexto para su realización. Investigación cualitativa, con datos obtenidos a través de cinco entrevistas con enfermeros de Servicio de Cirugía del municipio de Duque de Caxias, RJ, Brasil, realizadas entre agosto y setiembre del 2010, mediante un cuestionario semiestructurado. La metodología siguió la Teoría Fundamentada en los Datos. Los resultados muestran que el enfermero realiza el cuidado motivado por el compromiso y la satisfacción profesional, siendo la preservación del paciente su foco principal. El contexto es señalado como capaz de influir en las formas de trabajar, ya que la relación de cuidado se da en la interdependencia entre los entes involucrados y las condiciones de trabajo. Se concluye que los enfermeros de Servicio de Cirugía integran diversos factores, actuando a veces como agentes del cuidado indirecto, a pesar de las dificultades de un contexto complejo y específico.
\end{abstract}

DESCRIPTORES: Servicio de cirugía en hospital. Enfermería de quirófano. Atención de enfermería. 


\section{INTRODUCTION}

Work in an operating room unit entails many specific challenges. Features such as enclosure, the large volume of bureaucratic activities, close professional relationships and the subtlety of the anesthetic-surgical act are intertwined, forming nurses' professional scenarios. ${ }^{1}$ The Manual of Recommended Practice by the Brazilian Association of Operating Room, Anesthetic Recovery and Supply and Sterilization Center Nurses (SOBECC, as per its acronym in Portuguese $)^{2}$ divides the duties of operating room nurses into those related to the operation of the unit, technical and administrative duties, care activities, personnel management and clinical nursing assignments. ${ }^{2}$

Yet during their practice of care, nurses should have a perspective that goes beyond these functions, i.e., it is hoped that their attention is focused on issues related to care, which is essential and different than being/knowing/doing nursing. Nurses are responsible for setting the tone of patient embracement and establishing the care that will be provided. ${ }^{3}$ Therefore, it is relevant to discuss this practice in order to consolidate the actions of these operating room professionals.

One study with the aim to identify the activities performed by operating room nurses showed that these professionals' work is more related to preparation of the environment, control of supplies and the unit staff, rather than activities directly linked to caring for patients. ${ }^{4}$ The author concludes that the focus of operating room nurses is on other members of the surgical team and less on the patient. ${ }^{4}$ Other studies claim that operating room nurses are more focused on management tasks to the detriment of direct care of patients and the practice of humanized care. ${ }^{5}$

It is true that technological advances have transformed hospitals, requiring nurses to have a highly specialized profile. ${ }^{6}$ This requirement is accentuated by the high level of complexity of the operating room unit. Therefore, contemporary nursing faces the challenge of not permitting technological advances to overwhelm its essential characteristic of providing care.

Technology appears to benefit the biomedical model through its capacity to resolve problems, provide immediate return and reduce the time spent on tasks. However, the interpersonal element, based on human interaction, ${ }^{7}$ is impaired. Nursing works at the interface between the rigidity of scientific logic and moments related to the health-disease process, and is continuously in contact with despair, pain and suffering of people, which can shape its practice with an insensitive attitude that human complexity is not capable of understanding. ${ }^{7}$

These reflections led to the following research question: how do operating room nurses perform nursing care of patients during the perioperative period? To answer this question, the research aimed to understand the meaning of nursing care for operating room nurses. Through discussion of the ways in which these professionals provide care, the study intends to characterize their professional practice in this scenario, with emphasis on how the work context influences this practice.

In order to reflect on the research question above, the study aimed to identify forms of operating room nursing care, and to describe how the institutional context influences the practice of care by these professionals.

\section{THEORETICAL FRAMEWORK}

This study chose to base its theoretical constructs on symbolic interactionism, a reference from sociology that encourages discussion and interpretation of a given reality, in this case the experience of nurses. This concept considers the individual to be an active subject in his own actions and decisions. ${ }^{8}$

In this theoretical framework, human behavior is based on individual meanings for the elements of the world. These meanings arise from the interactive process, and are constantly modified through an on-going, interpretive process. These assumptions value interaction as the guiding axis of individual behavior, as it is from the value of each element, and the particularities of his own universe, that the subject establishes his action. ${ }^{9}$

Using this framework to guide a nursing research study is of great expression, considering that the human being is experiencing particular situations in different moments of his life, valuing the meaning of things and the world through interaction. The subject of nursing care, patients are offered the possibility of interpreting reality in the light of their meanings, and in the midst of the relationship of meanings with others. ${ }^{9}$

Symbolic interactionism favors qualitative, methodological approaches. Thus, it enables the production of knowledge based on reality, and simultaneously explains the variations observed. 
Thus, the diversity of the human experience is studied and understood. ${ }^{9}$

\section{METHODOLOGY}

The Grounded Theory (GT) methodology was used to develop this study. Theoretical construction with the GT methodology consists of an explanatory statement derived from data, which is systematically gathered and analyzed through the research process..$^{10}$ In this method, data collection, analysis and eventual theory maintain a close relationship with each other. Theory derived from data tends to resemble "reality" more than theory derived from the meeting of a set of concepts based on experience, or solely through speculation. This process begins with qualitative analysis, and can bring new knowledge to the field of the phenomenon. ${ }^{11}$

Empirical data were collected by means of a semistructured interview. Data were collected in a public hospital in the city of Duque de Caxias, in the Brazilian state of Rio de Janeiro, from August to September of 2010. This hospital provides urgent and emergency care, and serves as a reference for the municipalities in the region where it is located.

The operating room unit of the hospital has six rooms that are used to perform elective and obstetric surgeries and emergency procedures. The anesthetic recovery unit has five beds. During the data collection period, 460 surgeries were performed per month, $20 \%$ of which were general surgery, $20 \%$ orthopedic surgery, $42 \%$ obstetric procedures and $12 \%$ other specialties.

In addition to one nurse coordinator and a day-shift nurse, the operating room unit has one nurse per day who is responsible for the sector for 24 hours. Thus, the unit has a total of seven nurses with different shifts. Five of these seven nurses participated in the study. The nurses were invited to participate voluntarily with no obligation, through explanation of the study objectives. Each participant signed a free and informed consent form, in observance of resolution 196/96 concerning research involving human subjects.

The interviews took place in a private room in the study scenario (operating room unit), where participants were able to express their opinions calmly and with anonymity, and the information was kept confidential. In order to protect the respondents' identity, they were identified with colors: blue, black, red, green and purple. Two nurses had been working in the operating room unit for less than six months, and therefore were not included in the study.

The research proposal was approved by the Research Ethics Committee, registered under number: UnigranRio 0103.0.317.000-10. The interviews were digitally recorded and stored as MP3 files, then transcribed by the researcher to facilitate data analysis.

In order to ensure accuracy in the creation process, GT methodology procedures were applied using the data collected. This set of procedures is referred to as encoding. The encoding process is an integral part of the process of theory development, requiring a lot of concentration at the risk of losing the essence of the testimonies. ${ }^{10}$

Encoding is the process by which the data are divided, conceptualized and related. This process aims to give methodological rigor to the process of preparing data for analysis. ${ }^{10}$

From the combination of phenomena grasped in the study, development of the core category began, with the intent to represent the core explanatory theory, i.e., the main theme around which all categories revolve. ${ }^{11}$

The causal conditions, context, intervening conditions, strategies of action/interaction and consequences are the theoretical relations by which the categories are related (to each other and to the core category). This procedure forces the researcher to develop a theoretical framework and is called the paradigm of analysis. ${ }^{10}$

\section{RESULTS}

\section{Causal conditions - Understanding nursing care in the operating room}

According to reference authors of GT, causal conditions comprise the set of events and incidents that promote the occurrence or development of a given phenomenon. ${ }^{10}$ It is therefore worth highlighting the understanding that nurses in this scenario have of the care they provide, and the reasons that lead them to perform it.

The study data show that the operating room nurses understand the practical aspects of nursing care: the performance of predetermined procedures and routines. Relatedly, the devaluation of subjective care emerges, for example, as it relates to the emotional aspect. Thus, receptivity is described as a personal characteristic of nurses, which may or may not be present. 
Talking to the patient, it depends on each one [nurse], right? The obligation [of the nurse] is the patient's anamnesis and vital signs [...]. The fact that you talk to him, reassure him, it depends on each person; everyone is different. Each person may or may not do it...there are people who will not be sensitive, others who will be (Red).

Among the factors that motivate nurses to perform care are professional commitment, the possibility of witnessing a patient recover after a procedure, and meeting the patient's expectations. The data also point to a sense of empathy, where the nurse, sensitized by sometimes unnecessary and excessive exposure to the patient's body, strives to improve care.

What motivates me to [provide] care is the commitment I have with him, nothing else...here the only thing that motivates me is the patient (Black).

\section{Context - Performing nursing care immersed in a specific context}

The context is a specific set of properties pertaining to the phenomenon, representing the conditions where the interaction occurs. ${ }^{10}$ Importantly, in addition to the operating room environment, structure and characteristics, the context of this study includes intersectoral relations and interface with the healthcare institution as a whole.

The study data show that in the context of the operating room, bureaucratic activities performed by nurses arise from institutional decisions, necessary for the administrative and financial control of the surgical event. Additionally, the entire flow of patients, supplies and coordination of the healthcare staff in the operating room happens during nursing care, influencing and being influenced by it.

In the context of a healthcare facility, a care nurse is subordinate to immediate supervisors, coordinators and directors. The study participants' statements emphasize the importance of being able to count on the support of managers and directors, highlighting the difficulties that can arise when this is not present.

The fact of not having contact with the leadership makes it very difficult, because you end up having an obstacle in this line of communication. So this makes it difficult, yes [...] because I depend on my leadership to make things happen (Green).

Considering the operating room environment and the long tenure of professionals in this unit, one must also consider the influence of the multidisciplinary team on nurses' performance of care.

Of course personal and professional relationships count for a lot. The relationship with the staff, without a doubt, a positive relationship with the staff will positively facilitate care; whereas a negative relationship with the staff hampers care (Green).

In the institutional context, the operating room becomes dependent on the work conditions available. Thus, all supplies and other items necessary for risk-free comprehensive care depend on an adequate supply. The following statement illustrates how institutional difficulties can influence nursing care.

Caring for a [patient] here is not peaceful, due to lack of these things that I mentioned: there is not enough monitoring...these materials that are lacking during procedures (Blue).

The assumptions of symbolic interactionism argue that the relationship is dependent on the meaning attributed to the entity with whom one relates, be it a person, institution or object. This meaning, in turn, is modified according to the interactive process. Because care is relational, it will no doubt be influenced by the state of mind of the person with whom the interaction is established.

If you are in a quiet, peaceful environment, this influences [care], because I think when you're in a quiet environment to undertake your work, everything goes better (Red).

In addition to the presence of nurses and structural and tangible conditions, it is worth noting that the institutional dynamics was also mentioned when discussing the influence of the work context on professional practice in the operating room. The perception of nurses is that the entire context, in interrelationship with all spheres, is capable of influencing the care provided to the patient in the operating room unit.

She thought just her presence [director of nursing] could influence me, but it's not just that! Hospital management doesn't help you! The context is all wrong, all wrong... It does not help! The management outside influences my managers inside (Black).

\section{Strategies of action and interaction - Seeking to provide better care to surgery patients}

Operating room nurses encounter many difficulties while they are providing care. One of the strategies to continue to perform patient care is to 
seek motivation. The data show that the nurses try to motivate themselves to provide better care.

The quality of the service is much better when you're motivated [...]. When you do something that gives you pleasure, it is much better (Green).

Nursing care certainly has different aspects to be considered. If on the one hand it is important to use sensitivity, perception and even intuition, it is also important to draw on knowledge of sector routines, nursing practices and biological, anatomical and physiological foundations. To perform nursing care in the operating room, nurses seek general and specific knowledge about work in this sector.

To compose this body of information, the nurses associate knowledge gained in other jobs with information they acquire in the operating room. Moreover, they seek to improve their work.

I came from another operating room unit, where I saw it work...there was one nurse in the ARP, one in postoperative monitoring, one in pre...there was a nurse who stayed outside in the corridor, assisting the rooms (Black).

While the nurses seek to engage and create motivation to perform their work, it should also be remembered that nursing work is performed by the cohesion of a group. The nurses seek to value and respect the skills of each professional, as well as encourage interaction with staff as a way to harmonize the work environment.

You have to do this: you have to know the skills, you have to see which is the ability of that person, who has this skill, to try to put that person in a sector in which he or she best identifies with. Because then it gets easier for you to organize the work, even with the difficulties (Green).

Being understood as an integral member immersed in a particular context, the nurses seek to establish partnerships and create bonds of support as another strategy to accomplish their work, minimizing potential problems that may hinder the desired care for the operating room patient.

In some moments of routine care, nurses must act by establishing priorities, given that directly caring for all patients that pass through the unit is impossible. Thus, only those considered severe are cared for directly by a nurse. This is another strategy described by the study participants for working in the operating room.

In their prioritization of care, nurses end up delegating care of patients, supposedly those that are less severe. The nurses work in the operating room only if there is a serious complication, or if the staff requests their presence.

In fact, the nurse works very little in the [operating] room. Only if there is some complication (Red).

Given the context described above and its numerous difficulties, one of the ways that nurses perform their work is to maintain the patient as their top priority. The data show that care is simultaneously an attribute and source of inspiration for those who provide care.

We are able to work by focusing on the patient. The patient is the main focus. Focus on the patient and forget the other problems [...]. Create a shell: here is it, forget what's outside. You deal with what's outside later (Blue).

\section{Intervening conditions - Experiencing situations that alter the course of care in the operating room}

In symbolic interactionism, while the world of a particular individual is shaped by the meanings that he imputes to the elements around him, these can interfere in the relationships that the subject constructs. This is a constant process that is influenced by many factors, referred to as "intervening conditions" by GT theorists.

In this sense, when we think of elements that modify or alter the meaning of nursing care for operating room professionals, factors originating from the interactive process must be considered. The study data showed two types of intervening conditions, related to nurses' internal conditions and external conditions.

With regard to the internal conditions of study participants, the course of care may be altered due to their feelings, difficulties in assuming professional autonomy before the head of the unit, or with the other members of the nursing team.

The study data also point to some external factors which can influence the final outcome of care. These include factors related to the dynamics of the institution, difficulty obtaining supplies to perform the necessary procedures, and being involved with various issues, thus distancing themselves from nursing care.

Here, because of the large flow of patients, it's impossible for us to assist everyone [provide direct care]. My commitment to care is the same, but I don't always do the best job possible, because I am limited 
by situations in the hospital. Lack of material and such (Purple).

\section{Consequences - Understanding care as the result of several factors}

For the study participants, the nursing care performed in the operating room is the best possible, in large part due to the dedication of the nurses. Despite the obstacles, and considering the resources available, a willingness of the professionals to provide care was perceived.

But in terms of care, I think I have to do...I do the best I can, within the possibilities that are available to me (Green).

Considering that the care is performed within a context of possibilities and limitations, the data collected indicate two directions. In the first, care is considered to be good. In the opinion of the nurses, the act of caring in the operating room unit is satisfactory, despite the patients being inserted into a hospital setting that may not correspond the continuity of care provided in that sector.

I think that [the care] is satisfactory...we do what is needed, within the possibilities (Purple).

In contrast, a second portion of the data shows that because of all the difficulties, limitations and impossibilities, the nursing care performed in the operating room is unsatisfactory. However, it is the care that is possible in the current situation.

I think it can always be better, right? I always think when I leave here, I always have the impression that something was missing (Black).

The distinction between "good" and "possible" care leads to the greatest unfolding of the nursing work in the operating room. According to the data, care is the result of several integrated factors, not just the presence and work of nurses.

I think all the hospital staff...not just the nursing staff, but also staff from outside... all this will benefit the patient (Blue).

\section{DISCUSSION}

In light of the findings of this study, some reflections are important to be considered. It is noteworthy that nurses should seek elements that motivate them to strive to perform care. The institutional dynamics, however, does not allow the nurse to work together with the surgery patient. It is the ambivalence of feelings experienced between pleasure and suffering of working in this sector. ${ }^{12}$

The study data suggest the involvement and satisfaction that the nurses describe in their work. However, there are also signs of boredom, sadness and frustration. ${ }^{13}$ Many of these feelings come from a number of difficulties in interpersonal relationships and communication among staff, but they are also due to deficiency and lack of materials, equipment and nursing staff. ${ }^{14}$

All these elements compose the context of the operating room unit. One study describes the importance of the context being focused on care during the intraoperative period, so that patients are safe even when they are unconscious. ${ }^{15}$ The study reinforces that the operating room context has different meanings to the nursing staff, which consider it their field of work, whereas patients comprehend it as a strange place with potential threats.

In line with the considerations outlined so far, it is worth noting that care in the operating room takes place both directly and indirectly, in terms of attitudes towards the full recovery of the patient. This includes maintaining the environment harmonious and balanced. Thus, interventions by nurses should take place in a manner that maintains the environment in conditions that

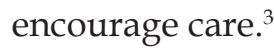

An important tool to qualify operating room nursing professionals is continuing education. ${ }^{16}$ The work of these nurses should promote discussion and reflection, and diffuse knowledge of nursing care in the unit where they work, addressing the technical and human dimensions, and offering a counterpoint to the prevailing biomedical dynamics.

Thus, it is hoped that the patient can in fact be the focus of nursing work within the operating room unit. To this end, perioperative nursing care will collaborate to positively influence the professional for good performance of care for the patient and family. ${ }^{17}$ This concept of care is most desirable for nursing, however, it is something that goes beyond the completion of tasks and independent and disconnected procedures.

In this sense, care is expected to be the expression of the interdependence between the rationality of technical knowledge and the protection of emotional subjectivity. Care comes to involve strategies that promote real change, reconstruction of knowledge and breaking of paradigms, emphasizing the construction of autonomy of surgical patients with a view towards their own freedom. ${ }^{18}$ 


\section{CONCLUSION}

From the data collected, the nurses described care in operation terms, focused on doing to the detriment of receptivity and subjectivity, inherent to the human condition. By disregarding subjective, emotional and relational aspects, for these professionals, care boils down to the execution of tasks and the relentless pursuit of reasonable working conditions.

From their statements, it is perceived that the nurses consider care to be a direct, cold and isolated action. "Providing care" boils down to performing a procedure or action. Offset by the fact that they cannot perform the necessary procedures because of the bureaucratic overload they experience, these professionals end up working with patients intermittently.

To perform care in the operating room, the nurses seek to be motivated by professional commitment, the need to reduce excessive exposure to patients' bodies and empathy for them, trying to meet their expectations.

With regard to context, there is an evident relationship of dependency for the success of the different forms of care in the operating room. Despite nursing care being dependent upon the relationship between professional and patient, the conditions imposed by the institutional context, in its various dimensions, can change the course of its development. Beyond the walls of the operating room, the context is configured as a space where different relationships are shown to be capable of influencing nurses' motivation and effort to perform care.

In this sense, professional relationships (with nursing staff and other categories), relationships with managers at higher levels of the institutional hierarchy, with the patient, and the nurses' relationships with themselves, all compete. Without the incentive of mediate and immediate supervisors, for example, labor relations are focused only on problems, hampering the service of care for patients.

Moreover, the work conditions of the institution, including availability of materials and supplies, are also able to influence the nursing care in the operating room, considering that this care has a technical dimension. It is important to consider the real difficulty in performing any type of work with patients in light of the institution's limitations. An issue that is evident in the testimonies of the study participants.
Given the characteristics of the context of the operating room, in order to fulfill their professional obligations, the nurses develop a number of strategies that they use to overcome the difficulties arising from interaction with the institution, their team, the patient and themselves. These strategies include their motivation and that of their team, the search for specific knowledge about the sector's activities, organization of the nursing staff, optimization of available resources and determining work priorities.

It is worth noting the nurses' strategy to seek to maintain the patient as the focus of their activities, in order to overcome the difficulties in the unit. Thus, nursing care, described above as an obligation, also becomes a source of inspiration for the nurse.

In conclusion, the nurses are seeking to do a satisfactory job for everyone involved. Nursing care in the operating room can be described as the result of nurses' efforts to integrate a set of conditions to perform their work, which, because of adverse conditions, is almost impossible.

\section{REFERENCES}

1. Reus LE, Tittoni J. A visibilidade do trabalho de enfermagem no centro cirúrgico por meio da fotografia. Interface Comunic Saúde Educ. 2012 Abr-Jun; 16(41):485-97.

2. Associação Brasileira de Enfermeiros de Centro Cirúrgico. Recuperação Anestésica e Centro de Material e Esterilização. Práticas recomendadas SOBECC - Centro cirúrgico, recuperação pósanestésica e Centro de Material e Esterilização. São Paulo (SP): SOBECC; 2009.

3. Silva DC, Alvim NAT. Ambiente do centro cirúrgico e os elementos que o integram: implicações para os cuidados de enfermagem. Rev Bras Enferm. 2010 Mai-Jun; 63(3):427-34.

4. Silva MVG. As atividades dos enfermeiros de centro cirúrgico: análise em instituições públicas e privadas [tese]. São Paulo (SP): Escola de Enfermagem da USP. Programa de Pós-Graduação em Enfermagem; 2005.

5. Barreto RASS, Barros APM. Conhecimento e promoção de assistência humanizada no centro cirúrgico. Rev Sobecc. 2009 Jan-Mar; 14(1):42-50.

6. Beck CLC, Gonzales RMB, Denardin JM, Trindade LL, Lautert L. A humanização na assistência dos trabalhadores de enfermagem. Texto Contexto Enferm. 2007 Jul-Set; 16(3):503-10.

7. Gomes AMT, Oliveira DC. A enfermagem entre os avanços tecnológicos e a inter-relação: representações do papel do enfermeiro. Rev Enferm UERJ. 2008 Abr-Jun; 16(2):156-61. 
8. Carvalho VD, Borges LO, Rêgo DP. Interacionismo simbólico: origens, pressupostos e contribuições aos estudos em Psicologia Social. Psicol Ciência Profissão. 2010 Mar; 30(1):146-61.

9. Blumer H. Symbolic interacionism: perspective and method. Englewood Cliffs (US): Prentice-Hall; 1969.

10. Strauss A, Corbin J. Pesquisa qualitativa: técnicas e procedimentos para o desenvolvimento da teoria fundamentada. $2^{\mathrm{a}}$ ed. Porto Alegre (RS): Artmed; 2008.

11. Dantas CC, Leite JL, Lima SBS, Stipp MAC. Teoria Fundamentada nos Dados - Aspectos conceituais e operacionais: metodologia possível de ser aplicada na pesquisa de enfermagem. Rev Latino-Am Enferm. 2009 Jul-Ago; 17(4):573-9.

12. Stumm EMF, Botega D, Kirchner RM, Silva LAA. Estressores e sintomas de estresse vivenciados por profissionais em um centro cirúrgico. Rev Min Enferm. 2008 Jan-Mar; 12(1):54-66.

13. Schmidt DRC, Dantas RAS, Marziale MHP. Ansiedade e depressão entre profissionais de enfermagem que atuam em blocos cirúrgicos. Rev
Esc Enferm USP. 2011 Abr-Jun; 45(2):487-93.

14. Braga EM, Berti HW, Risso ACMCR, Silva MJP. Relações interpessoais da equipe de enfermagem em centro cirúrgico. Rev Sobecc. 2009 Jan-Mar; 14(1):22-9.

15. Maya AMS. The intraoperative surgical context appreciations from a group of patients and from the nursing team. Invest Educ Enferm. 2012 Out-Dez; 30(3):304-12.

16. Ribeiro MB, Bonfim IM, Silveira CT. Estratégias de capacitação da equipe de enfermagem de um centro cirúrgico. Rev Sobecc. 2011 Jul-Ago; 16(3):21-9.

17. Fonseca RMP, Peniche ACG. Enfermagem em centro cirúrgico: trinta anos após criação do Sistema de Assistência de Enfermagem Perioperatória. Acta Paul Enferm. 2009 Jul-Ago; 22(4):428-33.

18. Lima MPO. Significado do cuidado de enfermagem para enfermeiras no contexto hospitalar: uma visão interacionista [dissertação]. Fortaleza (CE): Universidade Estadual do Ceará. Curso de Mestrado Acadêmico; 2010. 